\title{
Social Skills Program for Adolescents in Vulnerable Social Contexts
}

\author{
Vanessa Barbosa Romera Leme - Universidade do Estado do Rio de Janeiro, Rio de Janeiro, Brasil \\ Luana de Mendonça Fernandes - Universidade Salgado de Oliveira, Brasil \\ Neidiany Vieira Jovarini - Universidade Salgado de Oliveira, Brasil \\ Ana Maria El Achkar - Universidade Salgado de Oliveira, Brasil \\ Zilda Aparecida Pereira Del Prette - Universidade Federal de São Carlos, São Carlos, Brasil
}

\begin{abstract}
The study aims at examining the process indicators and evaluating the effects of a Social Skills program in social skills, selfefficacy and social support appraisals of 10 adolescents (age 13-17 years), of communities (slums) of Rio de Janeiro. An exploratory and promotion program in health was conducted with 10 sessions and process evaluation measures and results. The evaluation process included the record of behaviors in a protocol. The participants answered, before and after the intervention, the Social Skills Inventory for Adolescents, the Self-Efficacy Scale and the Social Support Appraisals Scale. The evaluation process revealed confidence indicators between adolescents and researchers. The results showed increased levels of social skills, social support of teachers and self-efficacy. Experimental and follow-up studies should be conducted to confirm the effectiveness of the program.

Keywords: adolescence, social skills, intervention, promotion
\end{abstract}

Programa de Habilidades Sociais para Adolescentes de Contextos Sociais Vulneráveis

\begin{abstract}
Resumo
O estudo examinou indicadores de processo e avaliou os efeitos de um programa de Habilidades Sociais no repertório de habilidades sociais, autoeficácia e percepção de apoio social de 10 adolescentes (idade de 13 a 17 anos), de comunidades (favelas) do Rio de Janeiro. Foi realizado um programa exploratório e com foco na promoção de saúde, composto por 10 encontros, com medidas de avaliação de processo e de resultados finais. A avaliação de processo incluiu o registro de comportamentos em um protocolo. Os participantes responderam, antes e após a intervenção, ao Inventário de Habilidades Sociais para Adolescentes, à Escala de Autoeficácia e à Escala de Percepção de Apoio Social. A avaliação de processo revelou indicadores de confiança entre os adolescentes e os pesquisadores. Os resultados indicaram aumento nos níveis de habilidades sociais, apoio social dos professores e autoeficácia. Estudos experimentais e de seguimento devem ser realizados para confirmar a efetividade do programa. Palavras-chave: adolescência, habilidades sociais, intervenção, promoção
\end{abstract}

Programa de Habilidades Sociales para Adolescentes de Contextos Sociales Vulnerables

\begin{abstract}
Resumem
El estudio examinó los indicadores de proceso y evaluó los efectos de un programa de Habilidades Sociales en el repertorio de habilidades sociales, autoeficacia y percepción de apoyo social de 10 adolescentes (13 a 17 años), de barrios marginales de Río de Janeiro. Un programa de exploración y promoción de la salud se llevó a cabo, y constó de 10 encuentros, con medidas de evaluación de proceso y resultados finales. La evaluación de proceso incluyó el registro de comportamientos en un protocolo. Los participantes respondieron, antes y después de la intervención, el Inventario de Habilidades Sociales para Adolescentes, la Escala de Autoeficacia y la Escala de Percepción de Apoyo Social. La evaluación del proceso reveló indicadores de confianza entre los adolescentes y los investigadores. Los resultados mostraron aumento en los niveles de habilidades sociales, apoyo social de los profesores y autoeficacia. Deben llevarse a cabo estudios experimentales y de seguimiento para confirmar la efectividad del programa.

Palabras-clave: adolescencia, habilidades sociales, intervención, promoción
\end{abstract}

Adolescence is a life cycle period characterized by both physical, psychological changes, and the expansion and modification of interpersonal relationships (Senna \& Dessen, 2012). Living with new groups and social contexts makes this time of life most prone to the emergence of vulnerabilities (Bornstein, Hahn, \& Haynes, 2010; Jacobs, Reinecke, Gollan, \& Kane, 2008). However, it can create new opportunities for a healthy trajectory of life.
Thus, there is currently the abandonment of the biologizing and negative view of adolescence by some scholars, together with a scientific practice to include, in the investigation, the identification of risk and protective factors (Senna \& Dessen, 2012). This conception of adolescence, focusing on healthy aspects, has contributed to interventions with adolescents living in a psychosocial vulnerability context (Libório \& Ungar, 2010). Research carried out at a national context, 
indicated that socially vulnerable teenagers are at greater condition of fragility front to some circumstances such as crime, family violence and sexual abuse; there is also more chance to make use of alcohol, tobacco and illicit drugs (Costa \& Dell 'Aglio, 2011; Fatori de Sá, Bordin, Martin, \& Paula, 2010; Fonseca, Sena, Santos, Dias, \& Costa, 2013;).

Maybe because of all these factors, we can see an increased interest of some researchers to conduct interventions with nonclinical populations in the social context (Franco \& Rodrigues, 2014; Silva \& Murta, 2009). Added to that, some scholars (Benson et al., 2006; Catalano, Berglun, Ryan, Lonczak, \& Hawkins, 2002) proposed that interventions with children and adolescents focused on the promotion of health rather than on the prevention and remediation of problems. This intervention model aligns with the approach called the Positive Youth Development - DPJ (Damon, 2004).

The focus of the interventions that follow this approach should be the development of various skills and abilities, for example, forming emotional bonds, developing social, emotional, cognitive and moral competencies and strengthening self-efficacy (Benson et al., 2006). The promotion of these aspects would have high predictive value in the healthy development and empowerment of children and adolescents to face future adversities (Catalano et al., 2002). These studies are close to the positive psychology that, according to Pacico and Bastianello (2014), focuses on the investigation of the qualities and of the positive characteristics of people associated with mental and physical health.

Nevertheless, Franco and Rodrigues (2014) found that within the national context, there is little intervention research that expand the focus beyond the prevention and emphasize health promotion and the positive development of adolescents (e.g., Minto, 2005; Silva \& Murta, 2009). Among these interventions, only the one carried out by Silva and Murta (2009) was based on a Social Skills training with adolescents from lowincome families. The results showed the promotion of diverse social skills such as expressing affection, making compliments, asking for help, refusing requests and initiating a conversation.

The Murta et al. (2012a) study can also be characterized as an intervention whose focus was both on prevention and on the promotion of health in adolescence. The intervention objective was to evaluate a program of interpersonal skills promotion and sexual and reproductive rights within 93 adolescents of a public school. The results showed an increase of social skills and highlighted the positive impact of the intervention in the sexist practices of adolescents.

Therefore, with this gap in knowledge, this study proposes the implementation and evaluation of a Social Skills program, with adolescents from vulnerable social contexts. The intervention, focusing on health promotion, aimed at developing interpersonal and social-skills, strengthening the individual to face the challenges in the transition to adulthood, such as finishing school, getting a job and establishing intimate relationships.

\section{Social Skills, Self-efficacy Beliefs and the Perception of Social Support}

A Social Skills Program (PHS) is set by Del Prette and Del Prette (2010) as an intervention procedure which includes various structured activities aimed at improving learning and / or developing social skills and, thus, maintain or improve the relationship between the person and their counterparts (family, friends, teachers and romantic partners). Once social skills are influenced by personal, situational and cultural factors there are, in the literature, various definitions and forms of implementation thereof (Beauchamp \& Anderson, 2010).

For Del Prette and Del Prette (2005), social skills represent “... the different social classes behaviors of an individual's repertoire, which contribute to social competence, promoting a healthy and productive relationship with others" (p. 31). Del Prette and Del Prette (2009) propose an organization of the relevant social skills in adolescence into six interdependent groups or classes, required for satisfactory interpersonal skills: empathy; self-control; civility; assertiveness; affective approach; and social resourcefulness.

Social skills are learned and improved throughout a life cycle, from interpersonal relationships within various social contexts (Del Prette \& Del Prette, 2005). However, when teenagers live in environments deprived of opportunities for the development and / or acquisition of social skills, they may experience interpersonal difficulties regarding psychosocial adaptation and psychological disorders (Campos, Del Prette, \& Del Prette, 2014; Young et al., 2012). In these situations, HS programs with adolescents are recommended. Although the focus is not on health promotion and on positive development, the HS programs with adolescents were implemented within international context (Harrel, Mercer, \& DeRosier, 2009; Kilian \& Kilian, 2011; Young et al., 2012). 
These studies showed and proved the effectiveness of HS programs in reducing externalizing behavior problems (Harrell et al., 2009; Kilian \& Kilian, 2011; Harrel et al., 2009), strengthen conceptions of self-concept and self-efficacy, (Harrel et al., 2009), decrease symptoms of depression and anxiety (Young et al., 2012) and improve relationships with peers and the academic performance (Kilian \& Kilian, 2011),

The literature suggests that interventions at promoting the learning of various social skills such as problem solving (Kilian \& Kilian, 2011; Silva \& Murta, 2009), empathy, emotional expression and self-control, assertiveness (Harrell et al., 2009; Kilian \& Kilian, 2011; Murta et al., 2012a; Silva \& Murta, 2009) and affective approach (Murta et al., 2012a), contribute to make adolescents develop positive beliefs and feel able to solve problems, control their feelings, deal with group pressure and seek emotional security relationships.

Also in this direction, some studies have indicated positive associations between social skills of adolescents and self-efficacy indicators (Erozkan, 2013; Harrell et al., 2009). According to Bandura (1989), self-efficacy can be defined as the set of beliefs that the person has in their ability to exercise control over events that affect their lives. Adolescents exposed to poverty and violence in the family and in the community can benefit from the strengthening of self-efficacy beliefs, in association with coping of behaviors, characterizing, therefore, a protective factor (Fontes \& Azzi, 2012).

According to Bandura (1989, 2006), self-efficacy beliefs have, as the main source, the experiences of direct realization, but they are also affected by the observing of the behavior of others, by verbal persuasion and physiological reactions, and emotional states. Similarly, PHS include cognitive-affective and behavioral components (verbal and nonverbal) and physiological that are shown through various techniques and, among them, the experiential modalities that enhance the beliefs of self-efficacy (Olaz, Medrano, \& Cabanillas, 2011).

Thus, it may be suggested that by developing an elaborate repertoire of social skills, the teenager may be exposed to successful experiences that increase the chance of mastery in performing future tasks, consolidating their self-efficacy beliefs. However, only the intervention of Harrell et al. (2009) with American teenagers and the Olaz, Medrano and Cabanillas (2011) with university students in Argentina, noticed the impact of PHS in self-efficacy beliefs of the participants. In the specific case of teenagers, the study Harrel et al. (2009) indicated the positive impact of teaching social skills on the self-efficacy of the participants. Nevertheless, teenagers recruited for intervention had interpersonal difficulties, which characterized the intervention focused on the reducing of problems.

Similarly, there is less evidence about the link between social skills and the perception of social support during adolescence. The perception of social support is conceptualized by Vaux et al. (1986) as the way people see themselves, feels cared for and supported by important people to them, such as families members, peers and teachers.

The relational people network, with whom adolescents have social and emotional bonds, expands in adolescence. In this sense, interpersonal relationships among adolescents with family members (Germano \& Colaço, 2012), colleagues (Valle, Bravo, \& Lopez, 2010) and teachers (Bowers et al., 2014; Sterret, Jones, McKee, \& Kincaid, 2011), can be understood as a support network that provides support to deal with negative life events. In addition, the social support network can create opportunities for the development of skills and social-skills, especially for the socioeconomically vulnerable ones (Libório \& Ungar, 2010). Thus, the network of social support and its perceptions is currently considered as one of the most important protective factors during adolescence (Juliano \& Yunes, 2014; Poletto \& Koller, 2011).

Social skills can contribute to satisfy social relationships and interactions guided by affection, reciprocity and balance of gains between the person and their interlocutors (Del Prette \& Del Prette, 2002, 2005). Thus, it is plausible that adolescents with better social skills, especially if linked to social competence, would find it easier to identify and seek for social support in its context, and at the same time, increase their host perception.

In this direction, some international studies have found positive correlations between social skills and the perception of social support to adolescents of different family configurations (Shin, Choi, Kim, \& Kim, 2010) and with symptoms of depression (Nilsen, Karevold, Røysamb, Gustavson, \& Mathiesen, 2013). However, no intervention in the national context in order to investigate if a PHS can promote the perception of social support and increase self-efficacy beliefs of teenagers from vulnerable social contexts was identified.

In short, some empirical indications support the hypothesis that a HS program can positively affect the beliefs of self-efficacy and the perception of social support, facilitating the emergence of resilience 
processes. According to Masten (2014, p.6), resilience can be defined as "the ability of a dynamical system to adapt successfully and in a positive way to disruptions that threaten its operation, its viability or development."

Resilience, understood as a process, involves dynamic interaction between internal and external resources of a person in crises, contributing to the emergence of positive results in the development (Poletto \& Koller, 2011). This perspective emphasizes the possibility of resilience developing in anyone over the life cycle, as well as opposing to the concept of resilience as a personality trait that emphasizes innate and immutable characteristics (Masten, 2014).

In this sense, some studies (Amparo, Galvão, Cardenas, \& Koller, 2008; Marques \& Dell'Aglio, 2013; Juliano \& Yunes, 2014; Noltemeyer \& Bush, 2013; Zolkoski \& Bullok, 2012) have shown that the social skills, self-efficacy and the perception of social support are, in the case of adolescents, internal and external resources which work interdependently to prevent or mitigate the negative effects of some psychosocial risks. Moreover, researchers that align to the Positive Youth Development approach (Benson et al., 2006; Catalano et al., 2002), highlight the importance of these personal skills and resources of the context for adolescents to optimize their potential at facing possible negative life circumstances, thus acting in the promotion of health and wellness.

Therefore, it can be said that social skills, self-efficacy and the perception of social support favor both the emergence of resilience processes and capabilities during the transition to adulthood. However, it is necessary to expand studies to clarify the relationship between these variables in a population of adolescents, especially those living in vulnerable contexts. For those, interventions focusing on promoting health that contributes to optimize their personal resources to deal with adverse demands of the context in which they live.

According to the regulations related to evidence-based practice (Kazdin \& Weiss 2003; Kellam \& Langevin, 2003; Murta, 2011), the development of effective programs involves assessing both the impact of the results and the process indicators, for example, the involvement of participants, acceptability of treatment and behaviors that signal search proximity and construction bond. Thus, assessments throughout the program enable the assessment of its viability and refine procedures for future interventions (Durlak, Weissber, \& Pachan, 2010; Murta, 2007, 2011). From these notes, this study aimed at examining process indicators, and assess the effects of a Social Skills Program (PHS), exploratory and focused on health promotion, social skills, the perception of social support of the family, friends and teachers and self-efficacy in adolescents in vulnerable social contexts.

\section{Method}

\section{Sample}

An intervention with non-clinical sample, under the pre- and post-test design was carried out. 15 teenagers were invited to participate in the Social Skills Program (PHS), however, five ( 3 boys and 2 girls, aged 13 and 15) dropped out and did not attend any meeting. The participants, aged between 13 and $17(M=$ 14.80 years, $S D=1.13$ ), were five girls and five boys attending a Non-Governmental Organization (NGO) and were enrolled, mostly in the II Cycle of Basic Education, (three in 8th grade, six in 9th grade and one in the 1st year of high school), from public schools in the central area of the city of Rio de Janeiro. Participants lived with about three people $(M=2.90, S D=.99)$.

Most of the breadwinners $(n=9)$ had studied between incomplete and complete elementary school and most of the monthly family income $(n=7)$ was around one or two minimum wages; the three others received between two and three times the value of the minimum wage. The inclusion criteria were adolescents younger than 18 and the delivery of the Informed Consent Form and signed by the legal guardian.

\section{Materials}

A Questionnaire with Demographic Information. It was developed for this study, to investigate information such as age, sex, school year, place of residence, number of people living with teenagers, householder's education and family monthly income.

Checklist of Intermediate Goals. It is an instrument developed by Murta $(2008,2011)$ to investigate process indicators in the implementation of programs and attitudes towards intervention: it presents a list of five verbal and nonverbal behaviors of adolescents that allows inferences about the "positive environment" of the session, trust and mutual support among the participants, for example, reporting feelings and problems and providing support to their colleagues. The occurrence of these behaviors should be observed and recorded every time they meet, regardless of who submitted the behavior. 
Social Skills Inventory for Adolescents (IHSA-Del-Prette). It is a tool developed by Del Prette and Del Prette (2009) to evaluate the social skills of teenagers from their self-reports about everyday situations. It presents 38 items that include different skills divided into six factors: (1) Empathy; (2) SelfControl; (3) Civility; (4) Assertiveness; (5) Affective Approach; (6) Social Resourcefulness. The responses are arranged in a Likert scale ranging from 0 (never) to 4 (always). Del Prette and Del Prette (2009) administered the instrument to 1172 adolescents of both sexes and found good internal consistency indices $(\alpha$ $=.89$ for the total scale and .68 to .85 for frequency factors).

Generalized Self-efficacy scale (EAG). It is originally from Germany and has been adapted to different cultures to identify the beliefs of self-efficacy in difficult situations of participants from different socioeconomic backgrounds and ages, including teenagers. The instrument consists of 10 items distributed on a Likert scale from 1 (Strongly Disagree) to 4 (Totally Agree). The EAG was adapted by Coimbra (2008) for a sample of adolescents and young adults and a good internal consistency value $(\alpha=.76)$ was found. In this study, the version of the scale validated by Leme, Coimbra, Gato, Fontaine and Del Prette (2013) was used in a sample of Brazilian adolescents. The authors demonstrated the construct validity and the invariance of the scale and its reliability was confirmed for the Brazilian sample $(\alpha=.80)$.

Perceived Social Support Scale (EPAS). It is an instrument developed by Vaux et al. (1986) to the American context to examine the perception of social support of children and adolescents in relation to family and friends (Social Support Appraisal - SSA). The scale consists of 30 items arranged in a Likert scale of 1 (completely disagree) to 6 (strongly agree) that includes four factors: (1) Perception of social support from the family; (2) Perception of social support from friends; (3) Perception of social support from teachers; (4) social support perception from others in general. Squassoni and Matsukura (2014) adapted the Portuguese version of the scale (Antunes \& Fontaine, 1995) to a Brazilian sample consisted of 218 students from 4th to 8 th grade. The authors found good and adequate internal consistency indices of the factors (family $\alpha=$ .57 ; Friends $\alpha=.72$; Teachers $\alpha=.79$; others $\alpha=.61$ ) and for the total scale $(\alpha=.74)$. In this study, the items of the "Others" factor were not included because it was more relevant to the purpose of the research to investigate social support perceived by adolescents of their specific networks.

\section{Procedure}

Ethical Considerations. The study was approved by the Ethics in Research in Human Beings Committee, according to process number 465.565, CAAE: 21635413.3.0000.5289. The participation of the adolescents was voluntary and endorsed by the delivery of and Informed Consent Form (ICF), previously signed by their legal guardians.

Data Collection. It was carried out in the classrooms of the NGO, which was coordinated by educators and social workers. At the beginning of the school year, the organization's professionals were went to the public elementary and high schools and invited students to attend the NGO, participating in activities such as, math and Portuguese classes, arts, health and cultural events taking place in periods different from school classes time. After the parents' authorization, teenagers participated in classes taught by university interns (educators). Teenagers were mostly of low socioeconomic status and community residents (slums) that were located near the downtown area of Rio de Janeiro.

In semester prior to data collection, three meetings were held with the program coordinator, social workers and educators to present the work. In these meetings, information on the routine and the target audience of the organization was collected; for example, socioeconomic status, age and education of the adolescents. As a result, the researcher scheduled with educators a time for the presentation of the research to the teenagers. On this occasion, the adolescents were given two copies of the Informed Consent (IC) to be signed by the person responsible for them. Before the data collection, the signed terms were delivered to the educational coordinator that gave them to the researcher.

The Social Skills Program (PHS) was organized with the following structure: (1) assessment of the needs of the participants; (2) training of the research team; (3) initial assessment (pre-test); (4) social skills program; (5) evaluation process; (6) evaluation of the results (post-test).

\section{Assessment of the Needs of the Participants}

Before the intervention, focus groups were conducted with the NGO adolescents for information on their perceptions about the relationship with family 
members, friends, teachers and romantic partners. The data obtained in those meetings with educators and focus groups, which will not be analyzed in the present study, have identified the needs and interests of the NGO users, personal and context resources and interpersonal difficulties that were then used in the preparation of the activities developed during the intervention.

\section{Training of the Research Team}

The PHS was conducted by the first author of the study and by three monitors (students of a graduate program in psychology) who had experience with interventions in the theoretical and practical field of social skills. Before starting the intervention, the monitors went through a training that involved participation in a 15 hour study group covering the following topics: (1) features and implementation of social skills programs; (2) use of group experiences and cognitive-behavioral techniques; (3) therapist social skills for the intervention in group with adolescents; (4) training to observe and record the behavior of the Checklist of intermediate targets; (5) prevention programs and health promotion characteristics with adolescents in vulnerable social contexts.

\section{The Social Skills Program (PHS) and Initial Assessments, Pro- cess and Results}

The preventive PHS consisted of 10 weekly meetings, each lasting about 120 minutes. In the first and last meeting, the participants answered the previously described instruments (Instruments section). The PHS with teenagers began with teaching social skills organized in an increasing order of complexity, as recommended by Del Prette and Del Prette (2002).

Social skills (classes and subclasses) focused on each meeting, based on Del Prette and Del Prette (2002, 2005), were: 2nd Meeting: Civility (initiating and maintaining conversation, ask and answer questions and praise and accept praise); 3rd Meeting: Empatby and human rights (adopting the other's perspective, interpreting and understanding their feelings and thoughts, experiencing the thrill of the other, keeping the control over it, expressing understanding and feelings related to the difficulties or successes of others and knowing the universal human rights).

4th Meeting: Emotional expressiveness and self-control (recognizing and naming theirs and the others' emotions, talking about emotions and feelings); 5th Meeting: Assertiveness (identifying and differentiating social performance as assertive, aggressive and passive); 6th Meeting: Assertiveness (expressing positive feelings, displeasure and disagreement and asking for behavioral change); 7th Meeting: Solving interpersonal problems (identifying a problem, formulating alternative resolution strategies, predicting outcomes and choosing a coping strategy, and resisting peer pressure); 8 Meeting: Affective approach (starting affective / sexual relationship and knowing sexual and reproductive rights.); 9th Meeting: Affective approach (saying what you like / dislike in loving relationships, apologizing and admitting flaws, ending loving relationship).

Considering the most important relationships and contexts during adolescence (Libório \& Ungar, 2010), the activities developed in each meeting focused on the interactions that adolescents reported taking place in the family environment, school and community. Thus, from meeting 2 to 6 relationships among teenagers and family, friends, romantic partners and teachers were focused. However, meeting 7 emphasized friends and romantic partners and meetings 8 and 9 focused on romantic partners relationships.

Teaching procedures included: (1) instructions about socially appropriate behavior; (3) presentation and discussion of articles and lyrics; (2) Group experiences (e.g. "Living the role of the other", "Neither passive nor aggressive" and "Regression in time" Del Prette \& Del Prette, 2002); (3) role play; (4) cognitive restructuring; (5) feedback; (6) reinforcement; (7) homework with auto registration behavior.

The role-play activities were prepared from information collected in the focus groups and the reports brought by the participants during the meetings. Among the situations reported by adolescents, circumstances involving assaults between adolescents and their partners stand out; demands to deal with violence; participation and death of people who are close due to the present drug trafficking in the community; and preferences for certain types of music (samba and Funk), and leisure activities (Funk balls). Such information was used to prepare the PHS activities in order to adapt them to the needs, interests and socio-cultural reality of adolescents who lived in communities (slums).

The meetings had a previously scheduled threepart structure. In the first part, participants described their housework and the facilitators made a brief summary of the previous session. Then they investigated the variables involved in carrying out the housework and discussed, together with the participants, alternatives 
to solve their difficulties. Next, the participants were invited to act, through role-play, some situations reported in the housework assignments, in order to train the main social skill of the previous meeting.

In the second part of the meeting, a day's theme exhibition was made involving a theoretical and a practical part. In the theoretical part, the material adapted to intervention programs with adolescents (Del Prette \& Del Prette, 2005, 2009; Bolsoni-Silva, 2009; Murta et al, 2011), news magazines and music were used. Activities for discussion and reflection in which the researcher related to social skill of the meeting the group mentioned were held. In the practical part, it the training of the target social skill of the meeting was made through group experiences (Del Prette \& Del Prette, 2002).

In the last session, the participants made a written or verbal evaluation of the meeting, and homework was assigned. Participants were given the task on a sheet for auto registration behaviors, thoughts and feelings related to social skill, something of the meeting.

At the end of all meetings, the monitors wrote notes on their perceptions about the behaviors of the participants (for example, reports of feelings and thoughts related to their interpersonal relationships and social skills, who had participated and demonstrated easiness or difficulty throughout the experiences and other activities), which were used for the preparation of a report. In addition, they filled the Checklist of intermediate goals. Before the next meeting, the researcher and the monitors met to discuss the most important facts of the report and of the Checklist. With this information, the activities that would be implemented in the following meetings in order to meet the needs of the group and of each participant were developed.

Data Analysis. The data collected before and after the intervention, in the PHS with the questionnaires were analyzed using the nonparametric Wilcoxon test that was run the in Statistical Package for Social Sciences for Windows (SPSS, version 18.0). As for the information collected during the procedure prior to each meeting, the monitors argued, about which the participants had manifested behaviors from the Checklist of intermediate goals. So when the pair of monitors agreed, the presence or absence of behaviors were noted globally, apart from the participants' amount of demonstrations. Later, frequencies were added to each behavior at the end of every meeting and the percentage was calculated, considering the total of possible occurrences, given the number of meetings.

\section{Results}

First, the results of pre and post intervention measures related to social skills, self-efficacy and perceived social support from family, friends and teachers are presented. (Table 1). Next, the process of evaluation results are described (Checklist of intermediate goals).

According to Table 1, it is noticed that the adolescents had the highest scores after the intervention of the social skills of empathy, self-control, assertiveness, emotional approach, social resourcefulness and overall skills in self-efficacy and perceived social support from teachers. Significant differences between the pre and post-intervention for the social skills of civility or in the score of perceived social support from family and friends were not found.

The frequencies of occurrence registered through the Checklist of intermediate goals were: (a) Report personal problems $=8$; (b) Report personal progress

Table 1

Social Skills, Perception of Social Support and Self-Efficacy: Comparison of Pre and Post Intervention Measures

\begin{tabular}{|c|c|c|c|}
\hline \multirow{2}{*}{ Variable } & \multirow{2}{*}{\multicolumn{2}{|c|}{$\begin{array}{l}\text { Intervention } \\
\text { Average Rank }\end{array}$}} & \multirow{2}{*}{$Z$} \\
\hline & & & \\
\hline Social Skills (HS) & Pre & Post & \\
\hline Empathy & .00 & 5.00 & $-2.68^{*}$ \\
\hline Self-control & 4.50 & 5.61 & $-2.35^{*}$ \\
\hline Civility & 5.00 & 5.00 & -1.49 \\
\hline Assertiviness & .00 & 4.50 & $-2.53 *$ \\
\hline Affective approach & .00 & 5.50 & $-2.81 *$ \\
\hline $\begin{array}{l}\text { Social } \\
\text { Resourcefulness }\end{array}$ & 2.00 & 5.89 & $-2.61 *$ \\
\hline $\begin{array}{l}\text { Total Score HS } \\
\text { Self-efficacy (AE) }\end{array}$ & .00 & 5.50 & $-2.80^{*}$ \\
\hline Total Score AE & 2.00 & 6.38 & $-2.41 *$ \\
\hline $\begin{array}{l}\text { Perception of Social } \\
\text { Support(PAS) }\end{array}$ & & & \\
\hline PAS Family & 2.50 & 3.75 & .00 \\
\hline PAS Friends & 3.17 & 6.50 & -1.846 \\
\hline PAS Teachers & 2.00 & 5.38 & $-2.42 *$ \\
\hline
\end{tabular}

Note. Z: Wilcoxon test.

${ }^{*} p \leq .05$ 
= 6; (c) Report feelings = 6; (d) Explain causes of their own behavior $=5$; (e) Provide support to colleague $=6$. Considering that the Total Possible events was 40 in eight meetings, it was found that $77.5 \%$ were observed (31) of the behaviors that characterize milestones over the meetings. Reporting personal problems was the behavior that occurred in all meetings, while explaining the causes of the behavior itself was the least manifested.

\section{Discussion}

The results of the comparison between pre and post-intervention indicated that teenagers improved, at significant levels, in scores of social skills of empathy, self-control, assertiveness, emotional approach, social resourcefulness and overall social skills. These results agree with other studies from abroad (Harrell et al., 2009; Kilian \& Kilian, 2011; Young et al., 2012) which showed increased social skills and other positive effects after the completion of a PHS, focusing on the prevention or remediation of difficulties.

According to some authors (Benson et al, 2006; Catalano et al., 2002), currently the identification itself of problematic aspects of adolescents (such as delinquency and psychopathological disorders), became less frequent in the investigations. At the same time, there was research on interventions that act on health promotion, instead of giving emphasis to preventing or reducing risk factors (Benson et al, 2006; Catalano et al., 2002; Damon, 2004).

Such studies adopt the Positive Youth Development approach and try to promote the personal resources of children and adolescents to deal with eventual psychosocial difficulties (Damon, 2004). According to Franco and Rodrigues (2014), in the national context, few interventions with adolescents have been conducted focusing on health promotion (e.g., Minto, 2005; Murta et al., 2012a; Murta \& Silva, 2009). Thus, this study contributes to this field of research to conduct a PHS with emphasis on the health promotion of teenagers from vulnerable social contexts. The study findings are also corroborated by the interventions in social skills conducted by Murta et al. (2012a) and Silva and Murta (2009).

PHS results showed positive effect on self-efficacy beliefs of adolescents, which is corroborated by the data from other studies (Harrell et al., 2009; Olaz et al., 2011). Improving self-efficacy beliefs can foster a person's exposure to situations of success (Olaz et al., 2011). In addition, according to Bandura (1989), the self-efficacy beliefs can positively influence the choices, the setting of goals and perseverance in pursuing goals, contributing to the development of motivation, academic achievement and well-being.

It is understood that while it is transformed by their interpersonal relationships and social contexts, the teenager should be seen as an active being that, according to the prospect of Bandura (2006), gives meaning to their experiences, is able to change their behaviors and change less healthy trajectories of life., Based on the results it can be assumed that the teenagers of this study have become more prepared to respond to the adversities present in its context, with less socio-emotional and interpersonal overload.

Finally, the intervention positively influenced the perception of social support of adolescents in relation to teachers, although it has not changed the perception of support in relation to family and friends. It might be suggested that this result is related to the fact that intervention has prioritized the teaching of some specific social skills for those contexts.

Thus, although it was expected that the PHS promoted the perception of social support, it is possible that the intervention did not include powerful enough components to affect trade between the teen and their friends and family, so their perception of their support did not modify. Future interventions could increase the number of meetings, so that it would also promote the social skills that facilitate the formation of links such as civility, affective approach and emotional expressiveness. One can assume that greater emphasis on those social skills generate significant changes in the adolescents' perception of social support from family and friends.

Several studies have documented the importance of social support from teachers for interpersonal and cognitive development of adolescents (Amparo et al., 2008; Bowers et al., 2014; Sterret et al., 2011.). Nevertheless, family and colleagues are indispensable sources of affection, warmth and security that should be present in the lives of adolescents (Germano \& Colaço, 2012; Valle et al., 2010). When they belong to a violent social context with lack of public policies that guarantee their rights, it is important to be able to count on the support of people in different contexts, especially family, school and community (Germano \& Colaço, 2012), to seek, in other places, the resources needed to address and overcome the crisis situations (Poletto \& Koller, 2011; Juliano \& Yunes, 2014). 
In this sense, an elaborate repertoire of social skills can facilitate this task because the establishment and maintenance of support networks are dependent on the quality of interpersonal relationships. Adolescents from vulnerable social contexts could make use of their social skills to activate or create links with people who can support them in times of difficulty, for example, with teachers who work as a protection factor that is present in the school context.

The PHS also aims at making the process of evaluation, which according to some authors (Kazdin \& Weiss 2003; Kellam \& Langevin, 2003; Murta, 2011), makes it possible to ascertain the involvement, the acceptability and the building of a bond while construction of the intervention. According to previous research (Murta et al., 2009; Murta \& Silva, 2009), the findings of the Checklist of intermediate goals can be taken as indicators that the participants were committed, and trusted in the intervention program to report problems and personal progress, to associate them to their feelings and provide support to colleagues.

However, it was found that the item "explain the own behavior" had less frequency than the others. Thus, despite not having jeopardized all of the intermediate goals, this goal could have been more encouraged, due to its possible relationship with the self-knowledge generated by the change of beliefs, feelings and behaviors (Guimarães, 2011).

Considering the obtained results, the program was relatively short and economical. This positive aspect can be attributed to the investment in the evaluation of the needs of adolescents and in contact with the NGO, over the six months prior to the intervention program. Such procedures may have favored the bond and trust between young people and the research team.

The knowledge of the living conditions and needs of intervention programs users allow the identification of risk and protective factors and definite which methodological strategies and social skills should be promoted (Franco \& Rodrigues, 2014; Murta, 2007). According to Durlak et al. (2010), as a whole, this information positively affects the final impact of the PHS and should, in fact, be adopted before the start of its implementation.

The results of this study suggest that the promotion of conditions related to positive development, such as social skills, self-efficacy and the perception of social support, may indicate a path for the development of well-being and quality of life of adolescents in an unfavorable economic situation (Amparo et al., 2008;
Marques \& Dell'Aglio, 2013; Juliano \& Yunes, 2014; Noltemeyer \& Bush, 2013; Zolkoski \& Bullok, 2012). The promotion of these skills can also generate resilience processes, as they operate in the empowerment of adolescents, enabling them to deal with adverse situations that require social skills, for example, required in relationships with family members, peers, teachers and romantic partners and in the work context.

A lot of research (Costa \& Dell'Aglio, 2011; Fatori de Sá et al., 2010; Fonseca et al., 2013) indicate that adolescents in vulnerable social contexts need to deal with situations such as violence in the community and in the family, which can lead to negative results within the development. The United Nations Program report data for Development (UNDP, 2014) showed that teenagers living in poverty are more penalized and have more difficulty to recover than others with access to basic social services such as education, security, and leisure and health. Therefore, considering the lack of interventions in the national context, focusing on positive development, the findings of the present study indicate that social skills in adolescence can be considered as a development protection factor, besides the problem prevention and the promotion of health and quality of life.

\section{Conclusion}

The results indicate that intervention focused on health promotion, from a PHS with adolescents from vulnerable social contexts, seems to strengthen their interpersonal and social-affective skills. It was found, among adolescents, an increase in their beliefs, in their ability to manage their lives and seek for help within their social support network, to face adverse events. The adopted intervention model is aligned with the Positive Youth Development approach and can contribute to the advancement of the field, to assess and promote strengths and virtues of adolescents.

Other relevant aspects of the research can be highlighted, such as: (1) the fact that the intervention was conducted with non-clinical sample, and in the context of teenagers' interaction, contributing to health promotion and prevention of socio-emotional difficulties in the transition to adulthood; (2) the use of process evaluation that allows the identification of aspects potentially related to the intervention; (3) the indication of the possible impact of social skills on self-efficacy and perceived social support, contributing to the literature of the area regarding the relationships 
between these variables and to interventions focused on health promotion.

We emphasize the relevance of the intervention method, using experiences and role-play adapted to the socio-cultural reality of adolescents. Along with the other procedures, these ingredients were essential to implement the PHS and may bring change of practices in future studies, ensuring greater ecological validity of the results obtained in these investigations.

The study results, although positive, need to be considered due to the following limits: (a) exploratory; (b) small number of participants and few meetings; (c) lack of control group or follow-up measures; (d) use of a single measurement process assessment; (e) initial and final evaluation ruled only in perceptions (reports) of adolescents about their own behaviors. Such limitations may be related to the absence of differences in pre and post-intervention regarding the social skills of civility and the perceptions of social support from family and friends. Thus, due to methodological limitations, the research findings should be replicated with experimental designs to determine their effectiveness.

Considering these limitations, future research may investigate the impact of a PHS on the repertoire of social skills, self-efficacy and perceived social support with a greater number of adolescents, in experimental study with follow-up measures. In addition, the behavior of adolescents could also be evaluated by family members and by their teachers. Other suggestions would be to consider increasing the number of meetings in order to promote the social skills of civility, empathy and human rights, emotional expressiveness and self-control, and interpersonal problem solving.

\section{References}

Amparo, D. M., Galvão, A., Alves, P., Cardenas, C., \& Koller, S. (2008). A escola e as perspectivas educacionais de jovens em situação de risco. Psicologia Escolar e Educacional, 12, 69-88.

Antunes, C., \& Fontaine, A. M. (1995). Diferenças na percepção de apoio social na adolescência: Adaptação do Social Support Appraisals. Cadernos de Consulta Psicológica, 10-11, 115-127. Retrieved from http://repositorio-aberto.up.pt/ bitstream/10216/15578/2/245.pdf

Bandura, A. (1989). Human agency in social cognitive theory. American Psychologist, 44, 1175-1184.
Bandura, A. (2006). Toward a psychology of human agency. Perspectives on Psychological Science, 1,164-180.

Beauchamp, M., \& Anderson, V. (2010). Social: An integrative framework for the development of social skills. Psychological Bulletin, 136(1), 39-64.

Benson, P. L., Scales, P. C., Hamilton, S. F., Sesma Jr., A., Hong, K. L., \& Roehlkepartain, E. C. (2006). Positive youth development so far core hypotheses and their implications for policy and practice. Search Institute Insights \& Evidence, 3(1), 1-13.

Bolsoni-Silva, A. T. (2009). Como enfrentar os desafios da universidade. São Carlos: Suprema Gráfica e Editora Ltda-EPP.

Bornstein, M. H., Hahn, C-S, \& Haynes, O. M. (2010). Social competence, externalizing, and internalizing behavioral adjustment from early childhood through early adolescence: Developmental cascades. Developmental Psychopathology, 22(4), 717-735.

Bowers, E. P., Johnson, S. K., Buckingham, M. H., Gasca, S., Warren, D. J. A., Lerner, J. V., \& Lerner, R. M. (2014). Important non-parental adults and positive youth development across mid- to lateadolescence: The moderating effect of parenting profiles. Journal of Youth Adolescence, 43(2), 897-918.

Campos, J. R., Del Prette, A., \& Del Prette Z. A. P. (2014). Depressão na adolescência: Habilidades sociais e variáveis sociodemográficas como fatores de risco/proteção. Estudos e Pesquisas em Psicologia, 14(2), 408-428.

Catalano, R. F., Berglund, M. L., Ryan, J. A. M., Lonczak, H. S., \& Hawkins, J. D. (2002). Positive youth development in the United States: Research findings on evaluations of positive youth development programs. Prevention \& Treatment, 5(15), 98-124.

Coimbra, S. (2008). Estudo diferencial de auto-eficácia e resiliência na antecipação da vida adulta (Tese de doutorado não publicada). Universidade do Porto, Portugal.

Costa, L. G., \& Dell’Aglio, D. D. (2011). Jovens em situação de vulnerabilidades social: A rede de apoio e o uso de drogas. In D. D. Dell'Aglio \& S. H. Koller (Eds.), Adolescência e Juventude: Vulnerabilidade e contextos de proteção (pp. 223-258). São Paulo: Casa do Psicólogo.

Damon, W. (2004). What is positive youth development? The Annals of the American Academy of Political and Social Science, 591(1), 13-24.

Psico-USF, Bragança Paulista, v. 21, n. 3, p. 595-608, set./dez. 2016 
Del Prette, A., \& Del Prette, Z. A. P. (2002). Psicologia das relações interpessoais e habilidades sociais: Vivências para o trabalho em grupo. Petrópolis: Vozes.

Del Prette, Z. A. P., \& Del Prette, A. (2005). Psicologia das habilidades sociais na infância: Terapia e educação. Petrópolis: Vozes.

Del Prette, A., \& Del Prette, Z. A. P. (2009). Inventário de habilidades sociais para adolescentes (IHS A-Del-Prette): Manual de aplicação, apuração e interpretação. São Paulo: Casa do Psicólogo.

Del Prette, A., \& Del Prette, Z. A. P. (2010). Programa vivencial de habilidades sociais: Características sob a perspectiva da análise do comportamento. In M. R. Garcia, P. Abreu, E. N. P. de Cillo, P. B. Faleiros \& P. P. Queiroz (Eds.), Comportamento e Cognição: Terapia comportamental e cognitiva (pp. 127-139). Santo André: ESETec.

Durlak, J. A., Weissberg, R. P., \& Pachan, M. (2010). A meta-analysis of after-school programs that seek to promote personal and social skills in children and adolescents. American Journal of Community Psychology, 45(3-4), 294-309.

Erozkan, A. (2013). The effect of communication skills and interpersonal problem solving skills on social self-efficacy. Educational Sciences: The Theory \& Practice, 13(2), 739-745.

Fonseca, F. F., Sena, R. K. R., Santos, R. L. A., Dias, O. V., \& Costa, S. de M. (2013). The vulnerabilities in childhood and adolescence and the Brazilian public policy intervention. Revista Paulista de Pediatria, 31(2), 258-264.

Fontes, A. P., \& Azzi, R. G. (2012). Crenças de autoeficácia e resiliência: Apontamentos da literatura sociocognitiva. Estudos de Psicologia (Campinas), 29(1), 105-114.

Franco, G, de R., \& Rodrigues, M. C. (2014). Programas de intervenção na adolescência: Considerações sobre o desenvolvimento positivo do jovem. Temas em Psicologia, 22(4), 677-690.

Germano, I. M. P., \& Colaço, V. de M. R. (2012). Abrindo caminho para o futuro: Redes de apoio social e resiliência em autobiografias de jovens socioeconomicamente vulneráveis. Estudos de Psicologia, 17(3), 381-387.

Guimarães, S. S. (2011). Técnicas cognitivas e comportamentais. In B. Rangé e Colaboradores (Ed.),
Psicoterapias cognitivo-comportamentais: Um diálogo com a pesquisa (pp. 170-193). Porto Alegre: Artmed.

Harrel, M. W., Mercer, S. H., \& DeRosier, M. E. (2009). Improving the social-behavior adjustment of adolescents: The effectiveness of a social skills group intervention. Journal of Child and Family Study, 18, 378-387.

Jacobs, R. H., Reinecke, M. A., Gollan, J, K., \& Kane, P. (2008). Empirical evidence of cognitive vulnerability for depression among children and adolescents: A cognitive science and developmental perspective. Clinical Psychology Review, 28(2), 759-782.

Juliano, M. C. C., \& Yunes, M. A. M. (2014). Reflexões sobre a rede de apoio social como mecanismo de proteção e promoção de resiliência. Ambiente \& Sociedade, 7(3), 135-154.

Kazdin, A. E. \& Weiss, J. R. (2003). Assessment and evaluation of interventions. In A. E. Kazdin (Ed.), Evidence-based psychotherapies for children and adolescents (pp. 408-435). New York: Guilford Press.

Kellam, S. G., \& Langevin, D. (2003). A framework for understanding "evidence" in prevention research and programs. Prevention Science, 4(1), 137-153.

Kilian, J. M., \& Kilian, D. W. (2011). A school intervention to increase prosocial behavior and improve academic performance of at-risk students. Improving Schools, 14(1), 65-83.

Leme, V. B. R., Coimbra, S., Gato, J., Fontaine, A. M., \& Del Prette, Z. A. P (2103). Confirmatory factor analysis of the generalized self-efficacy scale in Brazil and Portugal. Spanish Journal of Psychology, 16(E93), 1-11.

Libório, R. M. C., \& Ungar, M. (2010). Resiliência oculta: A construção social do conceito e suas implicações para as práticas profissionais junto a adolescentes em situação de risco. Psicologia: Reflexão e Crítica, 23(3), 476-484.

Marques, L. F., \& Dell’Aglio, D. D. (2013). Relações com a escola de fatores psicossociais positivos na adolescência. In Colaço, V. de F. R. \& A. C. F. Cordeiro (Eds.), Adolescência e juventude: Conhecer para proteger (pp. 103-133). São Paulo: Casapsi.

Masten, A. S. (2014). Global perspectives on resilience in children and youth. Child Development, 85(1), 6-20. 
Minto, E. C. (2005). Ensino de habilidades de vida para adolescentes vinculados a instituições profissionalizantes, no município de Ribeirão Preto/SP (Dissertação de mestrado). Universidade de São Paulo, Ribeirão Preto, SP, Brasil.

Murta, G. S. (2007). Programas de prevenção a problemas emocionais e comportamentais em crianças e adolescentes: Lições de três décadas de pesquisa. Psicologia: Reflexão e Crítica, 20(1), 1-8.

Murta, S. G. (2008). Programa de habilidades de vida para adolescentes: um Manual para Aplicação. Goiânia: Porã Cultural.

Murta, S. G., Borges, F. A., Ribeiro, D. C., Rocha, E. P., Menezes, J. C. L., \& Prado, M. M. (2009). Prevenção primária em saúde na adolescência: Avaliação de um programa de habilidades de vida. Estudos de Psicologia, 14(3), 181-189.

Murta, S. G. (2011). Aproximando ciência e comunidade: Difusão de programas de habilidades sociais baseados em evidências. In A. Del Prette e Z. A. P. Del Prette (Eds.), Habilidades sociais: Intervencõos efetivas em grupo (pp. 83-115). São Paulo: Casa do Psicólogo.

Murta, S. G., Ribeiro, D. C., Rosa, I. O., Menezes, J. C., Rieiro, M. R. S., Borges, O. S., Paulo, S. G., Oliveira, V. Miranda, V. H., Del Prette, A., \& Del Prette, Z. A. P. (2012a). Programa de habilidades interpessoais e direitos sexuais e reprodutivos para adolescentes: Um relato de experiência. Psico-USF, 17(1), 21-32.

Murta S. G., Rosa, I. O. Menezes, J. C. L., Rieiro, M. R. S., Borges, O. S., Paulo, S. G., Oliveira, V., Ribeiro, D. C., Del Prette, A., \& Del Prette, Z. A. P. (2012b). Direitos sexuais e reprodutivos na escola: Avaliação qualitativa de um estudo piloto. Psicologia: Teoria e Pesquisa, 28(2), 335-344.

Nilsen, W., Karevold, E., Røysamb, E., Gustavson, K., \& Mathiesen, K. S. (2013). Social skills and depressive symptoms across adolescence: Social support as a mediator in girls versus boys. Journal of Adolescence, 36(1), 11-20.

Noltemeyer, A. L., \& Bush, K. R. (2013). Adversity and resilience: A synthesis of international research. School Psychology International, 34, 474-487.

Olaz, F. O., Medrano, L. A., \& Cabanillas, G. A. (2011). Programa vivencial versus programa instructional de habilidades sociais: Impacto sobre a autoeficácia de universitários. In A. Del Prette e Z. A. P. Del Prette (Eds.), Habilidades sociais: Intervençōes efetivas em grupo (pp. 175-202). São Paulo: Casa do Psicólogo.

Pacico, J. C., \& Bastianello, M. R. (2014). As origens da psicologia positiva e os primeiros estudos brasileiros. In C. S. Hutz (Eds.), Avaliação em psicologia positiva (pp. 13-22). Porto Alegre: Artmed.

Poletto, M., \& Koller, S. H. (2011). Resiliência: Uma perspectiva conceitual e histórica. In D. D. Dell'Aglio, S. H. Koller, \& M. A. M. Yunes (Eds.), Resiliência e psicologia positiva: Interfaces do risco à proteção. $2^{\mathrm{a}} \mathrm{Ed}$. (pp. 19-44). São Paulo: Casa do Psicólogo.

Fatori de Sá, D. G., Bordin, I. A. S., Martin, D., \& Paula, C. S. (2010). Fatores de risco para problemas de saúde mental na infância/adolescência. Psicologia: Teoria e Pesquisa, 26(4), 643-652.

Senna, R. S. C. M., \& Dessen, M. A. (2012). Contribuições das teorias do desenvolvimento humano para a concepção contemporânea da adolescência. Psicologia: Teoria e Pesquisa, 28(1), 101-108.

Shin, H. S., Choi, H., Kim, M. J., \& Kim, Y. H. (2010). Comparing adolescents' adjustment and family resilience in divorced families depending on the types of primary caregiver. Journal of Clinical Nursing, 19(2), 1695-1706.

Squassoni, C. E., \& Matsukura, T. S. (2014). Adaptação transcultural da versão Portuguesa do Social Support Appraisals para o Brasil. Psicologia: Reflexão e Crítica, 27(1),71-80.

Silva, M. P., \& Murta, S. G. (2009). Treinamento de habilidades sociais para adolescentes: Uma experiência no Programa de Atenção Integral à Família. Psicologia: Reflexão e Crítica, 22(1), 136-143.

Sterret, E., Jones, D. J., McKee, L, G., \& Kincaid, C. (2011). Supportive non-parental adults and adolescent psychosocial function: Using social support as a theoretical framework. Journal of Community Psychology, 48(2), 284-295.

United Nations Program report data for Development [UNDP]. (2014) [Programa das Nações Unidas para o Desenvolvimento [PNUD]. Sustentar o progresso humano: Reduzir as vulnerabilidades e reforçar a resiliência. Relatório do desenvolvimento humano 2014. Retrieved from http://www. pnud.org.br/ 
Valle, J. F. del., Bravo, A., \& Lopez, M. (2010). Parents and peers as providers of support in adolescent's social network: A developmental perspective. Journal of Community Psychology, 38(1), 16-27.

Vaux A., Phillips, J., Holly, L., Thonson, B., Willians, D., \& Stewart, D. (1986). The social support appraisals (SSA) scale studies of reliability and validity. American Journal of Community Psychology, 14(2), 195-220.

Young, J. F., Makover, H. B., Cohen, J. R., Mufson, L., Gallop, R. J., \& Benas, J. S. (2012). Interpersonal psychotherapy-adolescent skills training Anxiety outcomes and impact of comorbidity. Journal of Clinical Child \& Adolescent Psychology, 41(5), 640-653.

Zolkoski, S. M., \& Bullock, L. M. (2012). Resilience in children and youth: A review. Children and Youth Services Review Journal, 34, 2295-2303.

Recebido 02/04/2015

Reformulado 29/06/2015

Aceito 12/07/2015

Nota das autoras:

Financial Support: FAPERJ (Process number E-26/111.153/2014).

Sobre as autoras:

Vanessa Barbosa Romera Leme é psicóloga (Unesp-Bauru), mestre em Psicologia do Desenvolvimento e Aprendizagem (Unesp-Bauru), doutora em Psicologia (FFCLRP-USP), com pós-doutorado (UFSCar), docente do programa de pós-graduação em Psicologia Social (mestrado e doutorado) da UERJ. Coordenadora do Núcleo de Estudos e Pesquisas sobre Desenvolvimento Humano e Relações Interpessoais (NuDeri).

E-mail: vanessaromera@gmail.com

Luana de Mendonça Fernandes é psicóloga pela Universidade Santa Úrsula, mestre em Psicologia Social (UNIVERSO-Niterói), especialista em psicologia clínica (UFF-Niterói).

E-mail: luapsi@gmail.com

Neidiany Vieira Jovarini é psicóloga (UFES), mestre em Psicologia Social (UNIVERSO-Niterói), pós-graduada em Atenção à Família (FAVI/ES) e Metodologia do Ensino Superior e Inovações Curriculares (FARO/RO), psicóloga clínica e hospitalar do Hospital de Humaitá-AM.

E-mail: neidivj@yahoo.com.br

Ana El Achkar é Pedagoga, Doutora e Mestre em Psicologia Social pela Universidade Salgado de Oliveira, Pós-graduada em Artes (UNILASALLE/RJ) e Psicopedagogia (UNIVERSO), Coordenadora da Pós-graduação Lato Sensu em Psicopedagogia FACNEC, membro do grupo de pesquisa Desenvolvimento Humano, Relações Interpessoais e Escolaridade/CNPq/UNIVERSO, membro no grupo de pesquisa NuDERI - Núcleo de Estudos e Pesquisas sobre Desenvolvimento Humano e Relações Interpessoais , do(a) Universidade do Estado do Rio de Janeiro - UERJ e Relações Interpessoais e Competência Social/CNPq/UFSCAR e diretora científica da Coleção Psico \& Pedagógicos da Editora Appris.

E-mail: anaelachkar@yahoo.com.br 
Zilda Del Prette é psicóloga, mestre em Psicologia Comunitária (UFPb), doutora em Psicologia Experimental (USP/ SP), com pós-doutorado pela Universidade da Califórnia e está vinculada ao programa de pós-graduação em Psicologia da UFSCar. É pesquisadora bolsista Nível 1A do CNPq, coordena grupo de pesquisa na área (http://www.rihs. ufscar.br) e grupo de Trabalho na Associação Nacional de Pesquisa e Pós-Graduação em Psicologia (ANPEPP).

E-mail: zdprette@ufscar.br

\section{Contato com as autoras:}

Vanessa Barbosa Romera Leme

Rua Francisco Xavier, 524, sala 10.006 Bloco D. Maracanã

CEP: 20550-900

Rio de Janeiro-RJ, Brasil

Telefone: (21) 2334-0108

E-mail:vanessaromera@gmail.com 